\title{
EFFECTS OF FARMYARD MANURE AND EXOGENOUS SPRAY OF BIO-STIMULANTS ON SEED QUALITY OF KABULI CHICKPEA
}

\author{
Karim Nouri ${ }^{1}$, Mohsen Janmohammadi ${ }^{1}$, Ali Asghar Aliloo ${ }^{1}$, \\ Mojtaba Nouraein ${ }^{1}$, Amin Abbasi ${ }^{1}$ \\ ${ }^{1}$ Department of Plant Production and Genetics, Agriculture College, University of Maragheh, P. O. Box 55181- \\ 83111, Iran
}

Link to this article: https://doi.org/10.11118/actaun.2021.059

Received: 20. 4. 2021, Accepted: 6. 12. 2021

To cite this article: NOURI KARIM, JANMOHAMMADI MOHSEN, ALILOO ALI ASGHAR, NOURAEIN MOJTABA, ABBASI AMIN. 2021. Effects of Farmyard Manure and Exogenous Spray of Bio-Stimulants on Seed Quality of Kabuli Chickpea. Acta Universitatis Agriculturae et Silviculturae Mendelianae Brunensis, 69(6): 665-675.

\begin{abstract}
Biostimulants have been defined as substances or materials extracted from plants, which have the capacity to beneficially modify plant growth. Chickpea (Cicer arietinum L.) is an annual legume of the family Fabaceae and it is a rich source of vitamins, minerals, dietary fiber, and protein. Two field experiments were conducted in Northwestern Iran (L1: Maragheh and L2: Hashtroud) to determine the effects of farmyard manure (FYM) application ( 0 and 20t/ha) and foliar application of bio-stimulants and chemical nutrients (acid salicylic, acid ascorbic, riboflavin, silicon dioxide nanoparticles, micronutrients, and distilled water as control) on nutritional characteristics of chickpea seeds. Results showed that there is a significant difference between seed quality of plant grown in two locations and the highest content of fatty acids (stearic acid, oleic acid, linoleic acid, linolenic acid), nitrogen, phosphorus, starch, and protein were recorded in seeds harvested from L2. Also, foliar application of micronutrient and silicon dioxide nanoparticles significantly increased dietary fiber, ash, starch, protein percentage. Concentrations of mineral nutrients (N, P, Fe, and Zn) significantly increased with the foliar application of micronutrients. Spray of acid salicylic and acid ascorbic increased the percentage of unsaturated fatty acids in both locations. Furthermore, the highest amount of flavonoid and crude oil was achieved by foliar spray of acid salicylic, silicon, and riboflavin. Although foliar spray of bio-stimulants and chemical nutrients improved seed quality in both locations, their positive effects were more pronounced in L2 where the soil and climate condition were partially better than L1. Overall, the best performance for major compounds of chickpea seeds was achieved by foliar spray of acid salicylic, micronutrients, and silicon dioxide nanoparticles in the FYM treatment. The present study indicate that improving the soil conditions is essential before foliar treatments.
\end{abstract}

Keywords: farmyard manure, foliar spray, locations, mineral nutrient, protein percentage

\section{INTRODUCTION}

Chickpea (Cicer arietinum L.) is the third most important pulse crop in the world after dry beans and dry peas about $15 \%$ of the world's total pulse productions belong to this crop. It is cultivated on 17.8 million hectares with a production of 17 million tons with a productivity of $965 \mathrm{~kg} / \mathrm{ha}$ (FAOSTAT, 2018). It is a good source of carbohydrates and protein, and protein quality is considered to be better than other pulses (Merga and Haji, 2019). Also, it is adaptable to wide climatic variation, has low production cost, and promotes biological fixation of atmospheric nitrogen (Pegoraro et al., 
2018). Therefore, it is a desirable plant for inclusion in crop rotations in these areas. Including legumes in crop rotation is considered as dual solution to improve soil quality and crop productivity. Legumebased cropping systems not only increase seed yields but also improve soil fertility through the biological $\mathrm{N}_{2}$-fixation of legume plants (Li et al., 2018). However, increasing legume productivity through optimization of agronomic practices is key to maximize the benefits of legumes in cropping (Gan et al., 2015).

However, chickpea production is not adequate to meet the needs of the food requirements of a growing population in semi-arid regions. Because of the limiting conditions of these regions, pressures of climate change, and lack of some appropriate agronomic management the chickpea yield is less than the global average in mentioned reign. However, it seems that through some crop management, its performance can be improved. A new approach to enhance crop quality and bioactive compounds under low precipitation and high evapotranspiration (ET) conditions of semi-arid regions is the exogenous application of plant growth stimulants and regulators. Some growth stimulants and natural compounds such as salicylates, vitamin B2 (riboflavin), silicon, ascorbic acid, and micronutrients can improve the yield and quality of various crops (Fernández and Brown, 2013; Allahveran et al., 2018; Farid et al., 2020).

Ascorbic acid (vitamin C) is an antioxidant molecule and a key substrate for the detoxification of reactive oxygen species and it seems that its foliar application can enhance plant growth (Shapiguzov et al., 2012; Shapiguzov et al., 2012; Qian et al., 2014; Akram et al., 2017). Also salicylic acid (SA) is an important plant hormone that has been described to play an essential role in the activation and regulation of multiple responses to biotic and to abiotic stresses (Janmohammadi et al., 2015; Hasanuzzaman et al., 2019; Koo et al., 2020; Ding and Ding, 2020). Riboflavin (also known as vitamin $\mathrm{B}_{2}$ ) is considered a key contributor of many metabolic enzymes and electron transport and has an important role in the cycle of citric acid, oxidation of fatty acids, photosynthesis, and DNA repair under stress conditions (Hanson et al., 2016; Abood and Abdulhamed, 2017; Hasanuzzaman et al., 2019).

Recently, the application of Si nanoparticles (Si-NPs) and micronutrients are highly regarded and their beneficial effects on plants are well established (Xie et al., 2015; Janmohammadi et al., 2016; Deshmukh et al., 2017; Rastogi et al., 2019). With regards to effects of environmental conditions and agronomic managements such as foliar spray on crop quality, their evaluation can provide valuable information about choosing appropriate agronomic management. The objective of this study was to evaluate the effects of foliar spray of acid salicylic, acid ascorbic, riboflavin, Si-NPs, and micronutrients on the qualitative characteristics of chickpea in Northwestern Iran.

\section{MATERIALS AND METHODS}

Two field experiments were conducted on experimental farms in the Maragheh as L1 (latitude $37^{\circ} 23^{\prime} \mathrm{N}$, longitude $46^{\circ} 16^{\prime} \mathrm{E}$ and altitude $1,485 \mathrm{~m}$ ) and Hashtroud region as L2 (latitude: $37^{\circ} 31^{\prime} \mathrm{N}$; longitude: 4653'E; altitude: 1,780 m), in North-west of Iran during the 2018-2019 growing seasons. During the first year, the field land was left to rest as fallow and in autumn it was plowed by moldboard. The experiments were conducted as a $(2 \times 6)$ analyzed as split-plot and as randomized complete block design with 3 replications. Two levels of farmyard manure (zero $\left.\left(\mathrm{FYM}_{0}\right), 20\left(\mathrm{FYM}_{20}\right) \mathrm{t} / \mathrm{ha}\right)$ as the first factor and foliar application of biostimulants and chemical nutrients $\left[\mathrm{S}_{1}\right.$ : spray of distilled water as control, $\mathrm{S}_{2}: 1 \mathrm{Mm}$ salicylic acid, $\mathrm{S}_{3}$ : $1 \mathrm{Mm}$ ascorbic acid, $\mathrm{S}_{4}: 1 \mathrm{Mm}$ riboflavin, $\mathrm{S}_{5}: 20 \mathrm{Mm}$ silicon dioxide nanoparticles, and $S_{6}$ : $1,000 \mathrm{ppm}$ micronutrients ( $\mathrm{Fe}, \mathrm{Zn}, \mathrm{Mn}, \mathrm{Cu}, \mathrm{Mo}, \mathrm{B}$ )] as the second factor have been considered. Foliar spraying was done in the early morning hours when temperatures was below $24^{\circ} \mathrm{C}$, since heat causes leaves' pores (stomata) to close. The soil texture at the Maragheh (L1) was sandy loam comprising of sand (53\%), silt (31\%) and clay (16\%), pH 7.85, electrical conductivity $(\mathrm{EC})=0.76 \mathrm{ds} / \mathrm{m}$, organic matter $=1.8 \mathrm{~g} / \mathrm{kg}$, nitrogen $(\mathrm{N})=0.058 \%$, available

I: Summary meteorological data for the 2019 chickpea growing season at the Maragheh and Hashtroud

\begin{tabular}{|c|c|c|c|c|c|c|c|c|c|c|}
\hline \multirow[t]{2}{*}{ Month } & \multicolumn{2}{|c|}{$\begin{array}{c}\text { Minimum temperature } \\
{\left[{ }^{\circ} \mathrm{C}\right]} \\
\end{array}$} & \multicolumn{2}{|c|}{$\begin{array}{c}\text { Maximum temperature } \\
{\left[{ }^{\circ} \mathrm{C}\right]}\end{array}$} & \multicolumn{2}{|c|}{$\begin{array}{c}\text { Mean temperature } \\
{\left[{ }^{\circ} \mathrm{C}\right]}\end{array}$} & \multicolumn{2}{|c|}{$\begin{array}{l}\text { Precipitation } \\
\text { [mm] }\end{array}$} & \multicolumn{2}{|c|}{$\begin{array}{c}\text { Mean Humidity } \\
{[\%]}\end{array}$} \\
\hline & L1 & $\mathrm{L} 2$ & L1 & L2 & L1 & L2 & L1 & L2 & L2 & L1 \\
\hline April & 2.9 & 1.6 & 11.5 & 9.2 & 7.5 & 6.4 & 16.3 & 35.2 & 19.3 & 51.3 \\
\hline May & 6.1 & 4.5 & 18.4 & 14.3 & 14.2 & 12.8 & 30.1 & 57.4 & 46.2 & 48.3 \\
\hline June & 11.4 & 8.1 & 24.5 & 18.7 & 17.6 & 15.6 & 17.3 & 23.6 & 45.2 & 39.6 \\
\hline July & 17.7 & 15.6 & 31.7 & 27.6 & 21.3 & 18.9 & 5.6 & 9.6 & 8.3 & 28.6 \\
\hline August & 21.0 & 19.4 & 33.4 & 29.1 & 28.0 & 24.5 & 1.6 & 3.5 & 4.2 & 23 \\
\hline
\end{tabular}

L1 - Maragheh; L2 - Hashtroud 
phosphorus $=5.67 \mathrm{mg} / \mathrm{kg}$, available potassium $(\mathrm{K})=342 \mathrm{mg} / \mathrm{kg}$, available zinc $(\mathrm{Zn})=0.71 \mathrm{mg} / \mathrm{kg}$, available iron $(\mathrm{Fe})=0.98 \mathrm{mg} / \mathrm{kg}$, total neutralizing value $=34 \%$. The soil of Hashtroud site (L2) was sandy loam [sand (58\%), silt (28\%), and clay $(14 \%)]$, and chemical properties were: pH 7.36, electrical conductivity $(\mathrm{EC})=0.98 \mathrm{ds} / \mathrm{m}$, organic matter $=1.72 \mathrm{~g} / \mathrm{kg}$, nitrogen $(\mathrm{N})=0.46 \%$, available phosphorus $=11.15 \mathrm{mg} / \mathrm{kg}$ and available potassium $(\mathrm{K})=412 \mathrm{mg} / \mathrm{kg}$, available zinc $(\mathrm{Zn})=0.95 \mathrm{mg} / \mathrm{kg}$, available iron $(\mathrm{Fe})=1.38 \mathrm{mg} / \mathrm{kg}$, total neutralizing value $=49 \%$. Both locations were part of regional semiarid highlands; in terms of climate, the area has been classified (according to Köppen and Geiger classification system) as a semi-arid temperate area (Peel et al., 2007). Growing season monthly average air temperature and total rainfall are presented in Tab. I. Kabuli chickpea (cv. Jam) was hand seeded at a depth of $5 \mathrm{~cm}$ in the first decade of April. The space between rows was $25 \mathrm{~cm}$ with eight rows per plot. A drip irrigation system with $20 \mathrm{~mm}$ laterals at each plant row was used for irrigation. Chickpea plants were harvested at ground level by hand from late June to early Julyas soon as each experimental plot reached to full maturity stage. For evaluation of seed quality characteristics, twenty plants from each treatment were selected at random in the harvested $2.0 \mathrm{~m}^{2}$. Atomic absorption spectrometry equipped with a Varian SpectraAA -240 model (Varian, Australia), was used to determine N, P, K, Fe, and Zn content. The total flavonoids content of the seed was determined by a colorimetric assay according to the method described by Youngjae et al. (2007) and Allahveran et al. (2018). A $1 \mathrm{~mL}$ aliquot of the appropriately diluted sample was added to a $15 \mathrm{~mL}$ tube containing $4 \mathrm{~mL}$ of deionized water. Then $0.3 \mathrm{~mL}$ of $5 \% \mathrm{NaNO}_{2}$ was added to this mixture, which was allowed to stand for $5 \mathrm{~min}$ at room temperature, and $0.6 \mathrm{~mL}$ of $10 \% \mathrm{AlCl}_{3} \cdot 6 \mathrm{H}_{2} \mathrm{O}$ was added. The mixture was allowed to stand for $6 \mathrm{~min}$ at room temperature, and $2 \mathrm{~mL}$ of $1 \mathrm{~mol} / \mathrm{L}$ $\mathrm{NaOH}$ was added, and the volume was made up to $10 \mathrm{~mL}$ with deionized water. The absorbance of the solution was measured immediately at $510 \mathrm{~nm}$. The results were expressed as catechin equivalents using a standard curve prepared from authentic catechin.

The protein percent of seeds were measured using a near-infrared seed analyzer (Zeltex, Maryland, USA). The dietary fiber content was determined using the enzymatic-gravimetric method of AOAC 985.29 (Polesi et al., 2011). The enzymatic hydrolysis of the starch and protein was carried out as follows: gelatinization in the presence of thermo-stable a-amylase (Termamyl $120 \mathrm{~L}, 97^{\circ} \mathrm{C}$, $15 \mathrm{~min}, \mathrm{pH}$ 6.0), incubation with pepsin (Sigma $\mathrm{P}-7000,40^{\circ} \mathrm{C}, 30 \mathrm{~min}, \mathrm{pH}$ 1.5) and incubation with amyloglucosidase (Sigma A-7255, $55^{\circ} \mathrm{C}, 30 \mathrm{~min}$, $\mathrm{pH}$ 4.0-4.6). Total starch content of all samples was determined using Total Starch HK Assay Kit based on AOAC Official Method 2002.02 (McCleary and Monaghan, 2002). In brief, a sample digested using -amylase containing amyloglucosidase, followed by incubation in a shaking water bath for $16 \mathrm{~h}$ to hydrolyze digestible starch. Hydrolysable starch was separated from resistant starch by washing with ethanol followed by centrifugation. The resistant starch portion was solubilized with potassium hydroxide solution. Both the hydrolysable starch and resistant starch fractions were digested using amyloglucosidase and were assayed for glucose concentration using a spectrophotometer at $510 \mathrm{~nm}$ to measure absorbance. Total starch was calculated as the sum of resistant starch and hydrolysable.

Oil content was determined gravimetrically by extraction with technical grade hexane (SigmaAldrich) in a Soxhlet apparatus (Cole-Parmer, Germany) for $10 \mathrm{~h}$ at $40^{\circ} \mathrm{C}$. The extracted oil was stored at $-18^{\circ} \mathrm{C}$ for further investigation in polypropylene containers. The determination of the fatty acids profile was carried out by GC (Agilent 7990B) equipped with a flame ionization detector and a TC-FFAP capillary column $(60 \mathrm{~m} \times 0.25 \mathrm{~mm}$ internal diameter, $0.25 \mu \mathrm{m})$. The temperature program was as follows: starting at $150^{\circ} \mathrm{C}$ and then heating to $190^{\circ} \mathrm{C}$ at $5^{\circ} \mathrm{C} / \mathrm{min}$, after $2 \mathrm{~min}$ followed by heating from $190^{\circ} \mathrm{C}$ to $250^{\circ} \mathrm{C}$ at $5^{\circ} \mathrm{C} / \mathrm{min}$. The final temperature $\left(250^{\circ} \mathrm{C}\right)$ was held for $8 \mathrm{~min}$. The fatty acids used as standards for the GC analyses (palmitic, stearic, and oleic acids) were from Sigma. The injector and detector temperatures were both set at $250{ }^{\circ} \mathrm{C}$. Injections of the methylated samples $(1 \mu \mathrm{L})$ were made in the splitless mode. Statistical analyses were performed using Statistical Analysis Systems (SAS 9.1) software. Differences were analyzed by ANOVA. Means were compared by the LSD test $(p<0.05)$.

\section{RESULTS}

Analysis of variance (ANOVA) for seed quality characteristics are shown in Tab. II. Results of the analysis showed that seed ash significantly affected by FYM application and foliar spray treatments $(p \leq 0.05)$. Also, triple effects of location $\times \mathrm{FYM} \times$ foliar spray were significant for seed ash percentage. The lowest seed ash content was related to plants grown in L1 (Maragheh) without FYM application and with no-foliar spray. However, the highest seed ash content was recorded in plants grown in L2 (Hashtroud) in the FYM treatment and with foliar application of micronutrient, Si-NPs, and Vitamin C (ascorbic acid). The effects of foliar treatment on seed ash content in L1 were more prominent than L2 (Tab. III). Assessment of dietary fiber showed that the main effect of location and foliar spray ( $p \leq 0.05$ ), as well as interaction effect of location $\times$ farmyard application $\times$ foliar spray, was significant (Tab. II; $p \leq 0.01$ ). Results showed that foliar spray of Si-NPs, salicylic acid, and micronutrients in L2, significantly increased the 


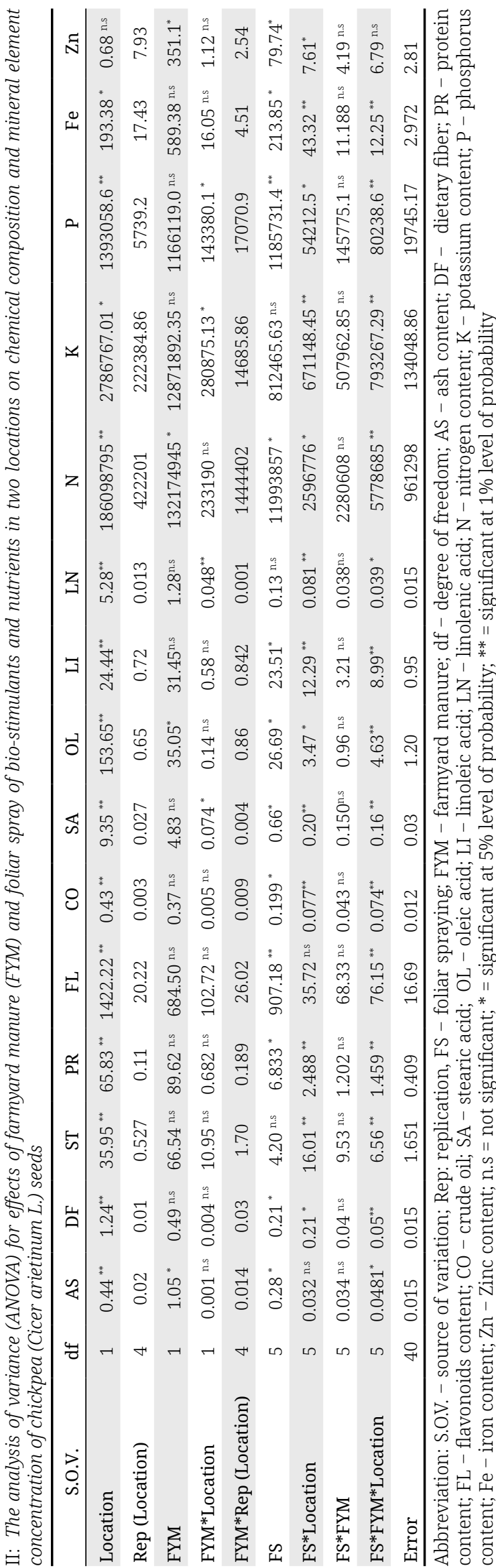

dietary fiber content. The lowest amount of crude fiber was recorded for plants grown in L1 without FYM application and foliar spray (Tab. III).

Evaluation of seed starch content indicated that the interaction effects of location $\times \mathrm{FYM} \times$ foliar spray were significant. Foliar spray of salicylic acid and ascorbic acid under FYM applied condition in L1 and all foliar treatments in the FYM treatment in the L2 significantly increased the seed starch content (Tab. III). Assessment of protein content in the chickpea seeds showed that the highest amount of protein obtained by foliar spray of Si-NPs, salicylic acid, and micronutrients in L2 (Fig. 1). However, the highest amount of protein in L1 was achieved by foliar spray of micronutrients. Mean comparison of the protein content between locations, FYM treatments, and different foliar sprays revealed that foliar spray of salicylic acid, Si-NPs, ascorbic acid, and micronutrients under FYM applied condition in L2 had more positive effects on seed protein content, respectively (Tab. III).

Seed flavonoid content in plants grown in L2 was $7 \%$ higher than those grown in L1. Foliar spray of salicylic acid and Si-NPs in the FYM treatment in L2 increased the seed flavonoid content significantly and the highest amount was recorded for mentioned condition (Tab. III). A positive effect of foliar spray of Si-NPs on seed flavonoid content also was recorded under FYM utilized condition in L1 (Fig. 2). The lowest flavonoid content was related to plants grown in L1 without FYM application and sprayed with distilled water or riboflavin.

Evaluation of total oil extracted from the seeds showed that plants grown in L2 had 4\% more oil than plants grown in L1 (Tab. III). The highest amount of seed oil was achieved by foliar spray of salicylic acid, ascorbic acid, and micronutrients along with FYM application in L2 (Tab. III). Furthermore, flame ionization-based detection gas chromatography for fatty acid profile revealed that comparison of the unsaturated fatty acid (oleic, linoleic, and linolenic acids) and saturated fatty acid (stearic acids) composition meaningfully affected by location, FYM, and foliar spray (Tab. II). The highest amount of saturated fatty acid was obtained by foliar spray of riboflavin, Si-NPs, and salicylic acid in the FYM treatment in L2. However, the highest oleic acid content was recorded in plants sprayed with acid salicylic and acid ascorbic under FYM applied conditions in L2. A relatively similar trend was observed for linoleic and linolenic acids. Foliar application of micronutrients on unsaturated fatty acids was more evident than a saturated fatty acid. Foliar spray of acid ascorbic in both locations considerably increased the unsaturated fatty acid (Tab. III).

Evaluations of seed nutrient content showed that N, P, and K) content was considerably affected by the treatments so that FYM application increased the seed nitrogen content by $10 \%$. The 


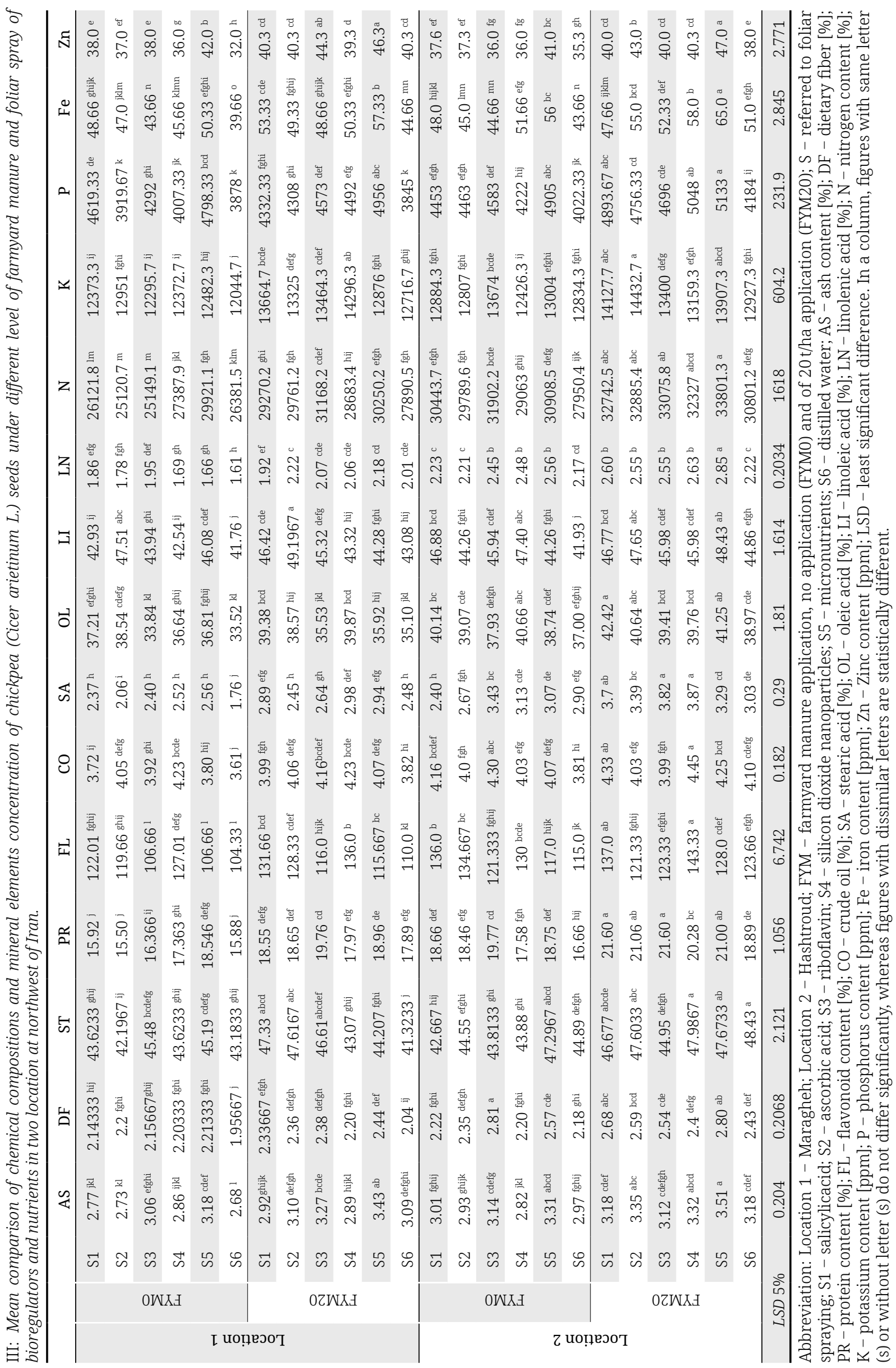




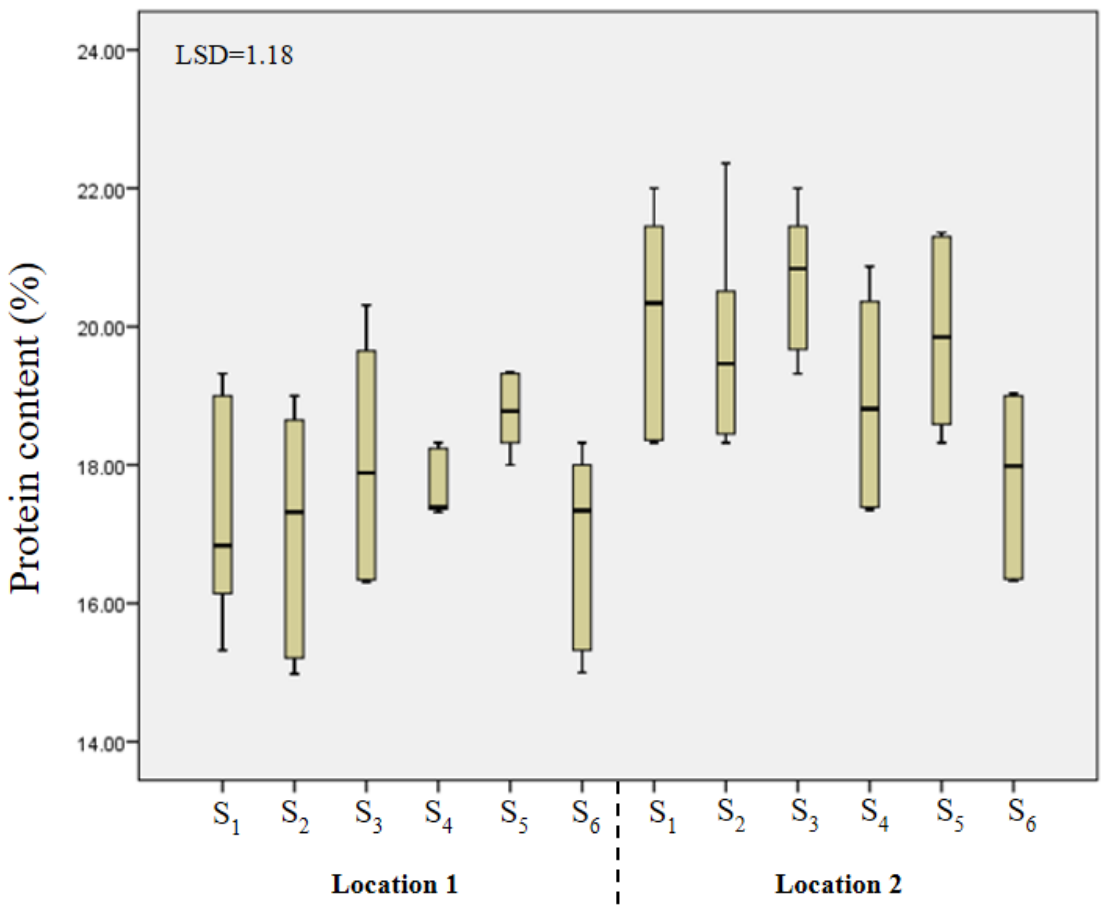

1: The effects of different foliar spray on protein content in the chickpea seeds in two locations in north-west portion of Iran. L referred to location, Location 1: Maragheh, Location 2: Hashtroud, S referred to foliar spray S1: acid salicylic, S2: acid ascorbic, S3: riboflavin, S4: silicon dioxide nanoparticles, S5: micronutrients, S6: distilled water. Any difference larger than Least Significant Difference (LSD) is considered a significant result.

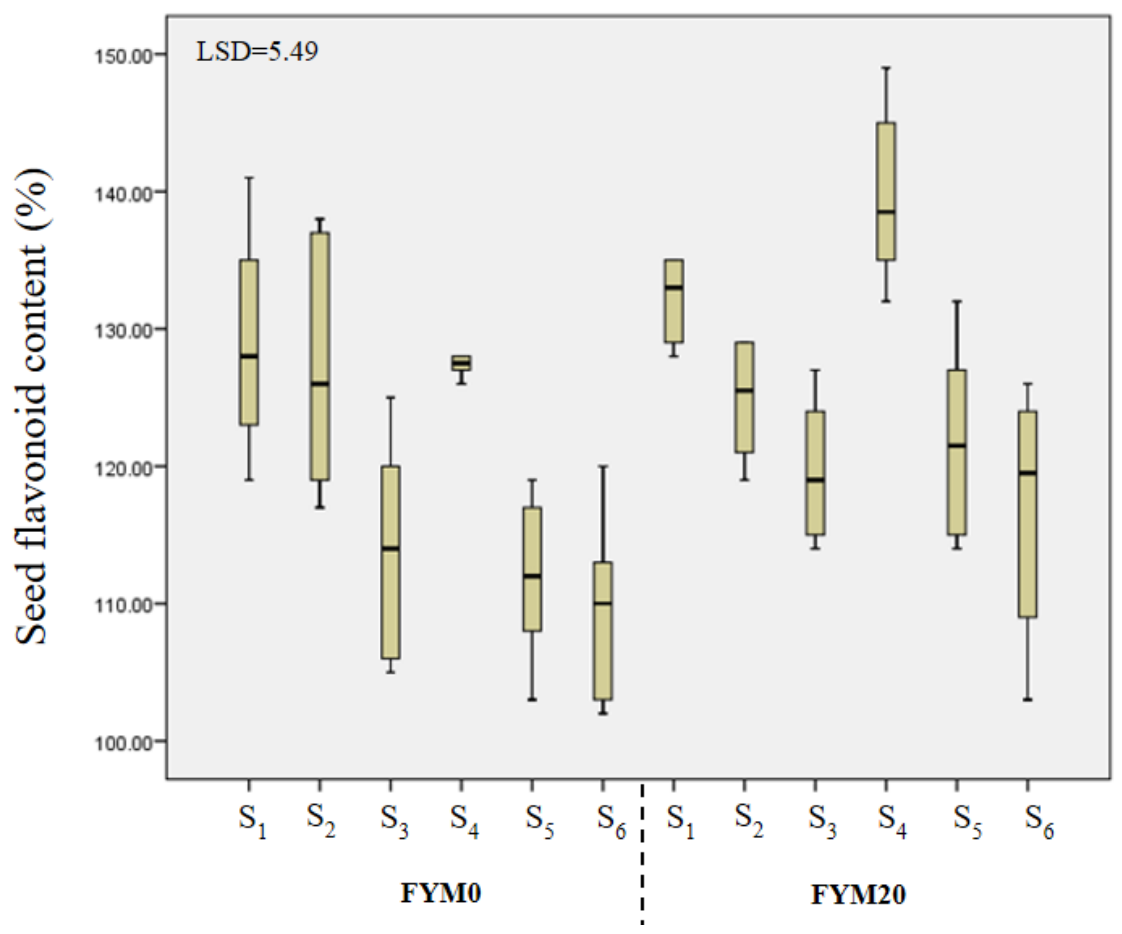

2: The effects of different foliar spray on flavonoid content of chickpea seeds under two level of farmyard manure application: zero (FYMO) and of 20 t/ha (FYM20) in northwest of Iran. S1: foliar spray of acid salicylic, S2: acid ascorbic, S3: riboflavin, S4: silicon dioxide nanoparticles, S5: micronutrients, S6: distilled water. Any difference larger than Least Significant Difference (LSD) is considered a significant result. 


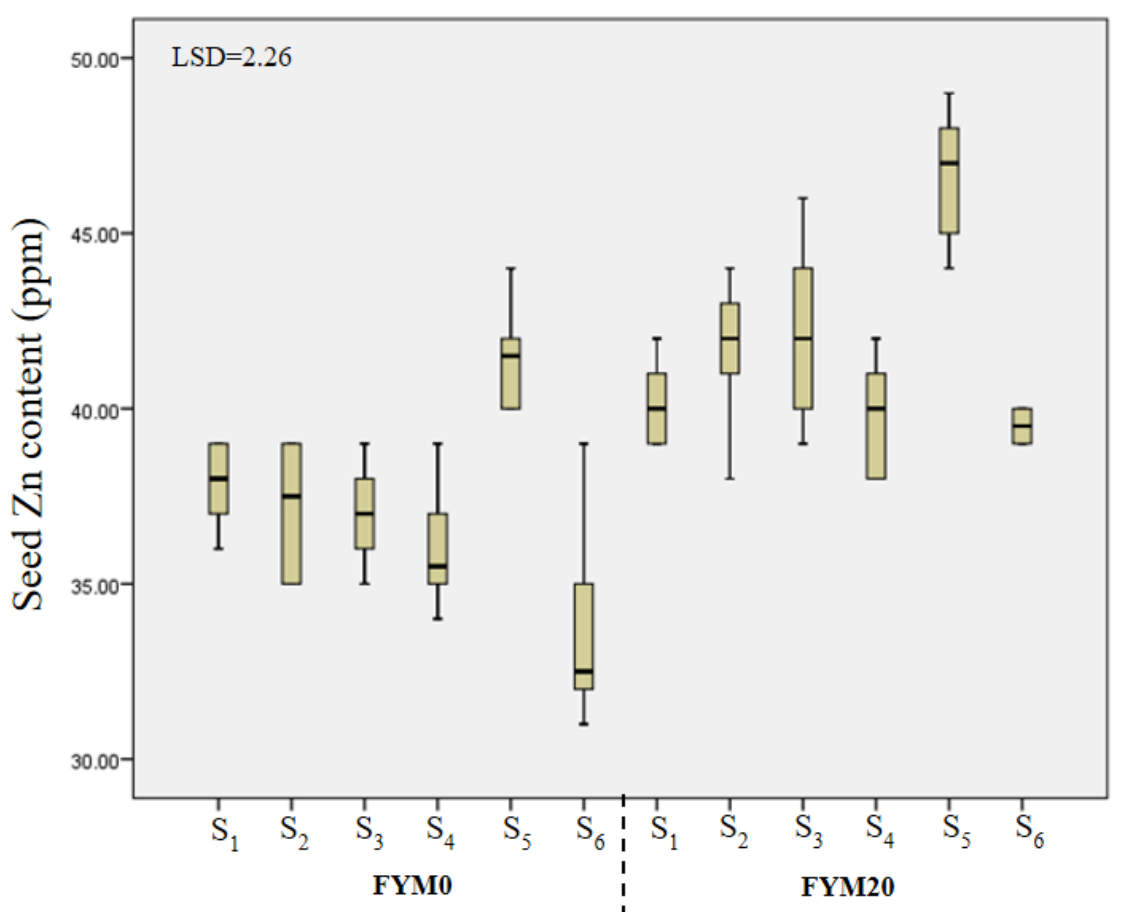

3: The effects of different foliar spray on Zn content of chickpea seeds under two level of farmyard manure application: zero (FYMO) and of 20 t/ha (FYM20) in northwest of Iran. S1: foliar spray of acid salicylic, S2: acid ascorbic, S3: riboflavin, S4: silicon dioxide nanoparticles, S5: micronutrients, S6: distilled water. Any difference larger than Least Significant Difference (LSD) is considered a significant result.

highest nitrogen content was recorded for plants grown under FYM applied conditions in L2 and sprayed with micronutrients and bio-stimulants. A similar trend was recorded for seed P content. Among foliar spraying treatments, the application of micronutrients and Si-NPs had the greatest positive effect on $\mathrm{N}$ and $\mathrm{P}$ content (Tab. III). The application of FYM in L2 caused a significant increase in seed K content. Foliar spray of riboflavin and salicylic acid along with FYM application significantly increased $\mathrm{K}$ content in L1 and L2, respectively (Tab. III). Furthermore, evaluation of Fe and Zn content revealed that foliar spray of micronutrients in the FYM treatment significantly increased seed Fe and Zn content in both locations. However, positive effects of micronutrient and FYM application on seed Zn content were more evident in L1. Moreover, foliar spray of Si-NPs and ascorbic acid under FYM utilized condition in L2 could increase seed Zn content significantly (Fig. 3).

\section{DISCUSSION}

The results showed that there is a significant effect of the location on all investigated quality characteristics of chickpea seeds. The best results for plants grown in L2. This can be attributed to the better edaphic and climatic conditions of this region. A similar conclusion was reached by Hoskem et al. (2017). The higher amount of available nutrients and better soil quality in L2 provided better seed quality by stimulating more growth. More precipitation during winter periods and well as the optimum temperature and low risk of heat stress of the end season caused a better performance of plants in the L2. It appears that plants with the relatively optimal establishment and sufficient growth can be more responsive to the supply of FYM and foliar spraying treatments (Navved et al., 2018). However, due to existence of some restrictions in soils of both locations, such as high $\mathrm{pH}$ and low precipitation, availability of some nutrients are not sufficient for the appropriate growth of chickpea plants. Therefore, a foliar application of mineral fertilization and some amendments seems to be necessary to complete the plant growth and acceptable seed quality especially during prolonged dry periods in late spring and summer (Alshaal and El-Ramady, 2017). Furthermore, ensuring adequate nutrition will assist the chickpea crop to generate wider canopy and a larger leaf area and this can significantly improve the effectiveness of foliar spraying treatments (Janmohammadi et al., 2017). Besides, correct rotations in L1 and considering the fallow in crop rotation programs during previous years, more precipitation, greater depth of arable soil, and greater water holding capacity in the soil caused the higher quality of seeds in L2. Crop and soil management such as reversal of previous crop residues and application of manure at the beginning of the season can have a significant impact on improving soil fertility and ultimately the quality 
of seeds harvested from the field. Furthermore, choosing a suitable site based on agro-climatic and soil zoning should be seriously considered. The zoning maps in the semi-arid regions should be based on rainfall, temperature, absolute minimum temperature, evapotranspiration, soil texture, soil erosion, nutrient availability in soil, soil depth, soil water holding capacity, and physicochemical properties of soil (Nabati et al., 2020). However, the deficiency of some micronutrients such as zinc and iron are still evident in L2, improving the quality of seeds with the use of micronutrient fertilizers also confirms this point.

The result showed that the effect of FYM on most of the studied characteristics was statistically significant and the highest seed quality was acquired by the application of FYM in L2. The soil of both sites had low organic matter owing to low, sporadic, and irregular rainfall and the low tendency to return crop residues to the soil due to lack of forage. For this reason, the application of FYM under mentioned condition significantly increases soil organic matter (SOM) and can stimulate crop growth by improving the physical, chemical, and biological properties of the soil (Nouraein et al., 2019). However, the better results obtained from the application of FYM in L2 can be attributed to the better climatic conditions in this region. FYM is known to improve crop production and seed quality under acceptable soil moisture regimes. In drier regions, use of manure is restricted by the historical perception so that manure can exacerbate negative effects of heat on crops resulting from the fact that ammonium in the manure can burn the crop if manure is placed in the planting hole (Murungweni et al., 2016). Also, it seems that the application of FYM by improvement of soil conditions, facilitation of root growth, increasing the nutrients uptake, had prepared a uniform canopy as a suitable base for better absorption of bio-stimulants and micronutrients. The results are consistent with the results of some previous works (Pasandi et al., 2018; Kheyrkhah et al., 2018).

The application of micronutrients significantly increased the zinc content compared to the control. A similar pattern of results was obtained by Hidoto et al. (2017). Also, foliar application of ascorbic and salicylic acids increased the content of identified fatty acids. These basic findings are consistent with research showing that foliar spraying of salicylic acid and putrescine stimulated the accumulation of important metabolites such as different amino acids, vitamins, sugars, organic acids, amines, fatty acids (Khan et al., 2019).

Although most of the studied traits and seed quality characteristics were affected by foliar spray treatments, the behavior of traits against foliar spraying treatments was different. chickpea seeds are the preferred source of protein and dietary fiber since they have a rich source of digestible proteins and the use of appropriate management to improve seed protein content may significantly affect community health and food security. Seed storage proteins of chickpea are mainly comprised of albumin, globulin, and glutelin (Chang et al., 2011). In this experiment, it was observed that to improve the protein content, in addition to the use of FYM, the application of micronutrients, salicylic acid, and Si-NPs should be considered as an important agronomic management option. The findings are directly in line with previous findings of Janmohammadi et al. (2017). This trend also was recorded for seed $\mathrm{N}$ content, stearic acid, linoleic acid, and dietary fiber. Due to some soil restrictions in semi-arid regions such as low soil moisture and high $\mathrm{pH}$, foliar application of micronutrients can provide nutrient requirements rapidly. In line with previous studies, foliar feeding of micronutrients enhanced the accumulation of nitrogen and improved seed yield, starch contents, and protein content (Potarzycki and Grzebisz, 2009).

The highest flavonoid content and fatty acides content was recorded under relatively favorable soil conditions (in L2 with FYM application) and by foliar application of acid salicylic and Si-NPs. Also, the best morphological growth was recorded under mentioned conditions. These results indicate that there is a direct relationship between growth rate and flavonoid content. Dry legumes are staple and potentially functional foods, being good sources of polyphenols and flavonoids (Segev et al., 2010). Besides their nutritional value, chickpea seeds contain various phenolic compounds. Phenolic compounds are of particular interest because of their contribution to the seed color and sensory characteristics as well as several biological properties (Magalhães et al., 2017). Although the foliar application of growth regulators and biostimulants improved seed characteristics to some extent, their greatest effect was observed under better climatic and soil conditions and with the utilization of FYM. This was especially apparent for riboflavin. This suggests that the application of foliar treatments under unfavorable semiarid conditions cannot be effective individually. Application of FYM by improving the plant establishment and expansion of the canopy can provide a better uniform basis for foliar treatments. It is encouraging to compare this finding with that found by Janmohammadi et al. (2015) and Nouraein et al. (2019). 


\section{CONCLUSION}

From the present investigation, it may be concluded that soil management using farmyard and crop management with foliar application of bio-stimulants were able to improve the quality of seeds and nutritional value of Kabuli chickpeas in both areas. Also, results showed that the application of FYM in L1 which has previously been under poor management, incorrect rotations, and experienced intensive agriculture are very necessary. Foliar feeding with micronutrients and foliar spray salicylic acid as well as Si-NPs under FYM applied conditions noticeably increased seed quality especially in the site with better soil and climate conditions (L2). Improving soil conditions can lead to prominent effects of foliar treatments. Our results revealed that foliar spray of Si-NPs, micronutrients and salicylic acid as simple and accessible crop management options can be effective in the semiarid regions. Further research is needed to prove their positive functions at the subcellular level.

\section{Acknowledgements}

The authors are grateful to the research council of the University of Maragheh for the financial support of this project. Also, the authors would like to thank experts of Central Laboratory (depended on Laboratory Network of Strategic Technologies) for their assistance in biochemical analysis.

\section{REFERENCES}

ABOOD, N. M. and ABDULHAMEED, Z. A. 2017. Response of some sorghum (Sorghum bicolor, L. Moench) cultivars to foliar spraying of riboflavin growth, grain yield and proline content. Journal of Plant Production, 8(11): 1093-1101.

AKRAM, N. A., SHAFIQ, F. and ASHRAF, M. 2017. Ascorbic acid-a potential oxidant scavenger and its role in plant development and abiotic stress tolerance. Frontiers in Plant Science, 8: 613.

ALLAHVERAN, A., FAROKHZAD, A., ASGHARI, M. and SARKHOSH, A. 2018. Foliar application of ascorbic and citric acids enhanced 'Red Spur' apple fruit quality, bioactive compounds and antioxidant activity. Physiology and Molecular Biology of Plants, 24(3): 433-440.

ALSHAAL, T. and EL-RAMADY, H. 2017. Foliar application: from plant nutrition to biofortification. Environment, Biodiversity and Soil Security, 1(1): 71-83.

CHANG, Y. W., ALLI, I., KONISHI, Y. and ZIOMEK, E. 2011. Characterization of protein fractions from chickpea (Cicer arietinum L.) and oat (Avena sativa L.) seeds using proteomic techniques. Food Research International, 44(9): 3094-3104.

DESHMUKH, R. K., MA, J. F. and BÉLANGER, R. R. 2017. Role of silicon in plants. Frontiers in Plant Science, 8: 1858.

DING, P. and DING, Y. 2020. Stories of salicylic acid: A plant defense hormone. Trends in Plant Science, 25(6): 549-565.

FAOSTAT. 2012. FAO Production Yearbook. Rome: FAO. Available at: http://apps.fao.org [Accessed: 2021, April 15].

FARID, M. Z., QURESHI, K. M., SHAH, S. H., QURESHI, A. A., UMAIR, M. and SHAFIQ, H. 2020. Foliar application of micronutrients improves growth, productivity and fruit quality of strawberry (Fragaria ananassa Duch). Journal of Animal and Plant Sciences, 30(4): 905-912.

FERNÁNDEZ, V. and BROWN, P. H. 2013. From plant surface to plant metabolism: the uncertain fate of foliar-applied nutrients. Frontiers in plant science, 4: 289.

GAN, Y., HAMEL, C., O'DONOVAN, J. T., CUTFORTH, H., ZENTNER, R. P., CAMPBELL, C. A. NIU, Y. and POPPY, L. 2015. Diversifying crop rotations with pulses enhances system productivity. Scientific reports, 5: 14625.

HANSON, A. D., BEAUDOIN, G. A., MCCARTY, D. R. and GREGORY, J. F. 2016. Does abiotic stress cause functional B vitamin deficiency in plants? Plant Physiology, 172(4): 2082-2097.

HASANUZZAMAN, M., NAHAR, K., FUJITA, M., OKU, H. and ISLAM, T. (Eds.). 2019. Approaches for enhancing abiotic stress tolerance in plants. CRC Press.

HIDOTO, L., WORKU, W., MOHAMMED, H. and BUNYAMIN, T. 2017. Effects of zinc application strategy on zinc content and productivity of chickpea grown under zinc deficient soils. Journal of Soil Science and Plant Nutrition, 17(1): 112-126.

HOSKEM, B. C. S., DA COSTA, C. A., NASCIMENTO, W. M., SANTOS, L. D. T., MENDES, R. B. and DE CAMPOS MENEZES, J. B. 2017. Productivity and quality of chickpea seeds in Northern Minas Gerais, Brazil. Revista Brasileira de Ciências Agrárias, 12(3): 261-268.

JANMOHAMMADI, M., AMANZADEH, T., SABAGHNIA, N. and ION, V. 2016. Effect of nano-silicon foliar application on safflower growth under organic and inorganic fertilizer regimes. Botanica Lithuanica, 22(1): 53-64. 
JANMOHAMMADI, M., NASIRI, Y., ZANDI, H., KOR-ABDALI, M. and SABAGHNIA, N. 2015. Effect of manure and foliar application of growth regulators on lentil (Lens culinaris) performance in semiarid highland environment. Botanica Lithuanica, 20(2): 99-108.

JANMOHAMMADI, M., YOUSEFZADEH, S., DASHTI, S. and SABAGHNIA, N. 2017. Effects of exogenous application of nano particles and compatible organic solutes on sunflower (Helianthus annuus L.). Botanica Serbica, 41(1): 37-46.

KHEYRKHAH, M., JANMOHAMMADI, M., ABBASI, A. and SABAGHNIA, N. 2018. The effects of micronutrients ( $\mathrm{Fe}$ and $\mathrm{Zn}$ ) and beneficial nano-scaled elements ( $\mathrm{Si}$ and $\mathrm{Ti}$ ) on some morphophysiological characteristics of oilseed rape hybrids. Agriculture (Pol'nohospodárstvo), 64(3): 116-127.

KHAN, N., BANO, A., RAHMAN, M. A., GUO, J., KANG, Z. and BABAR, M. A. 2019. Comparative physiological and metabolic analysis reveals a complex mechanism involved in drought tolerance in chickpea (Cicer arietinum L.) induced by PGPR and PGRs. Scientific reports, 9: 2097.

KOO, Y. M., HEO, A. Y. and CHOI, H. W. 2020. Salicylic acid as a safe plant protector and growth regulator. The Plant Pathology Journal, 36(1): 1-10.

LI, J., LIU, K., ZHANG, J., HUANG, L., COULTER, J. A., WOODBURN, T., LI, L. and GAN, Y. 2018. Soil-plant indices help explain legume response to crop rotation in a semiarid environment. Frontiers in plant science, 9: 1488.

MAGALHÃES, S. C., TAVEIRA, M., CABRITA, A. R., FONSECA, A. J., VALENTÃO, P., ANDRADE, P. B. 2017. European marketable grain legume seeds: further insight into phenolic compounds profiles. Food Chemistry, 215: 177-184.

MCCLEARY, B. V. and MONAGHAN, D. A. 2002. Measurement of resistant starch. Journal of AOAC International, 85(3): 665-675.

MERGA, B. and HAJI, J. 2019. Economic importance of chickpea: Production, value, and world trade. Cogent Food and Agriculture, 5(1): 1615718.

MURUNGWENI, C., VAN WIJK, M. T., SMALING, E. M. A. and GILLER, K. E. 2016. Climate-smart crop production in semi-arid areas through increased knowledge of varieties, environment and management factors. Nutrient Cycling in Agroecosystems, 105(3): 183-197.

NABATI, J., NEZAMI, A., NEAMATOLLAHI, E. and AKBARI, M. 2020. GIS-based agro-ecological zoning for crop suitability using fuzzy inference system in semi-arid regions. Ecological Indicators, 117: 106646.

NOURAEIN, M., KOUCHAK-KHANI, H., JANMOHAMMADI, M., MOHAMADZADEH, M. and ION, V. 2020. The effects of tillage and fertilizers on growth characteristics of Kabuli chickpea under Mediterranean conditions. Acta Technologica Agriculturae, 23(1): 18-23.

NOURAEIN, M., SKATARIC, G., SPALEVIC, V., DUDIC, B. and GREGUS, M. 2019. Short-term effects of tillage intensity and fertilization on sunflower yield, achene quality, and soil physicochemical properties under semi-arid conditions. Applied Sciences, 9(24): 5482.

NAVEED, S., REHIM, A., IMRAN, M., MUHAMMAD, A. B., MUHAMMAD, F. A. and FIAZ, A. 2018. Organic manures: an efficient move towards maize grain biofortification. International Journal of Recycling of Organic Waste in Agriculture, 7: 189-197.

PASANDI, M., JANMOHAMMADI, M., ABASI, A. and SABAGHNIA, N. 2018. Oil characteristics of safflower seeds under different nutrient and moisture management. Nova Biotechnologica et Chimica, 17(1): 86-94.

POLESI, F., SARMENTO, S. B. S, BORALLI, C. and DOS ANJOS, P. 2011. Composition and characterization of pea and chickpea starches. Brazilian Journal of Food Technol., 14(1): 74-81.

PEEL, M. C., FINLAYSON, B. L. and MCMAHON, T. A. 2007. Updated world map of the Köppen-Geiger climate classifcation. Hydrology and Earth System Sciences, 4(2): 439-473.

PEGORARO, R. F., ALMEIDA NETA, M. N. D., COSTA, C. A. D., SAMPAIO, R. A., FERNANDES, L. A. and NEVES RODRIGUES, M. 2018. Chickpea production and soil chemical attributes after phosphorus and molybdenum fertilization. Ciência e Agrotecnologia, 42(5): 474-483.

POTARZYCKI, J. and GRZEBISZ, W. 2009. Effect of zinc foliar application on grain yield of maize and its yielding compone. Plant, Soil and Environment, 55(12): 519-527.

QIAN, H. F., PENG, X. F., HAN, X., REN, J., ZHAN, K. Y. and ZHU, M. 2014. The stress factor, exogenous ascorbic acid, affects plant growth and the antioxidant system in Arabidopsis thaliana. Russian journal of plant physiology, 61(4): 467-475.

RASTOGI, A., TRIPATHI, D. K., YADAV, S., CHAUHAN, D. K., ŽIVČÁK, M., GHORBANPOUR, M., EL-SHEERY, N. I. and BRESTIČ, M. 2019. Application of silicon nanoparticles in agriculture. 3 Biotech, 9(3): 90.

SIDDIQUI, H., AHMED, K. B. M., SAMI, F. and HAYAT, S. 2020. Silicon nanoparticles and plants: current knowledge and future perspectives. In: HAYAT S., PICHTEL, J., FAIZAN, M. and FARIDUDDIN, Q. (Eds.). Sustainable Agriculture Reviews. Vol 41. Cham: Springer, pp. 129-142. 
SEGEV, A., BADANI, H., KAPULNIK, Y., SHOMER, I., OREN-SHAMIR, M. and GALILI, S. 2010. Determination of polyphenols, flavonoids, and antioxidant capacity in colored chickpea (Cicer arietinum L.). Journal of food science, 75(2): S115-S119.

SHAPIGUZOV, A., VAINONEN, J., WRZACZEK, M. and KANGASJÄRVI, J. 2012. ROS-talk-how the apoplast, the chloroplast, and the nucleus get the message through. Frontiers in Plant Science, 3: 292.

XIE, Z., SONG, R., SHAO, H., SONG, F., XU, H. and LU, Y. 2015. Silicon improves maize photosynthesis in saline-alkaline soils. The Scientific World Journal, 2015: 245072.

YOUNGJAE, S., RUI HAI, L., JACQUELINE, F., NOCKC, D. H. and CHRISTOPHER, B. W. 2007. Temperature and relative humidity effects on quality, total ascorbic acid, phenolics and flavonoid concentrations, and antioxidant activity of strawberry. Postharvest Biology and Technology, 45(3): 349-357.

Contact information

Mohsen Janmohammadi: jmohamad@alumni.ut.ac.ir (corresponding author) 
